\section{Use of Monoclonal Anti-Receptor Antibodies to Probe the Expression of the Low Density Lipoprotein Receptor in Tissues of Normal and Watanabe Heritable Hyperlipidemic Rabbits}

\author{
Manfred Huettinger, Wolfgang J. Schneider, Y. K. Ho, \\ Joseph L. Goldstein, and Michael S. Brown \\ Departments of Molecular Genetics and Internal Medicine, \\ University of Texas Health Science Center at Dallas, \\ Southwestern Medical School, Dallas, Texas 75235
}

bstract. Watanabe Heritable Hyperlipidemic (WHHL) rabbits, like humans with familial hypercholesterolemia, have a genetic defect in the low density lipoprotein (LDL) receptor. WHHL fibroblasts produce a low molecular weight precursor form of the receptor that is not glycosylated normally and is not transported to the cell surface at a normal rate. In the current studies, we have used a monoclonal antibody that reacts with the rabbit $L D L$ receptor to extend these findings to intact rabbits. We have made the following observations: (a) In normal rabbits the liver and adrenal glands synthesize high molecular weight mature LDL receptors like those in fibroblasts. (b) In WHHL rabbits the adrenals express only the low molecular weight receptor precursor, and the liver expresses no detectable receptors. (c) When injected intravenously, the radioiodinated antiLDL receptor monoclonal antibody is cleared from plasma 6-10-fold faster in normal than in WHHL rabbits, with specific uptake demonstrable in livers and adrenals of normal but not WHHL rabbits. The latter finding raises the general possibility that the total number of cell surface receptors expressed by an animal or human in vivo can be estimated by measuring the rate of clearance of an intravenously injected monoclonal antibody directed against the receptor of interest.

Dr. Huettinger is the recipient of a postdoctoral fellowship from the Max Kade Foundation, Inc. Dr. Schneider is the recipient of an Established Investigatorship from the American Heart Association.

Received for publication 10 February 1984 and in revised form 25 April 1984.

J. Clin. Invest.

(C) The American Society for Clinical Investigation, Inc.

0021-9738/84/09/1017/10 \$1.00

Volume 74, September 1984, 1017-1026

\section{Introduction}

The Watanabe Heritable Hyperlipidemic (WHHL) ${ }^{1}$ rabbit is a useful animal counterpart of familial hypercholesterolemia (reviewed in reference 1). WHHL rabbits, like humans with familial hypercholesterolemia, have a mutation in the gene encoding the low density lipoprotein (LDL) receptor. Animals that are homozygous for this defect express $<5 \%$ of the normal number of functional LDL receptors, as measured in cultured fibroblasts (2), liver and adrenal membranes (3), and isolated hepatocytes (4). As a result, these animals catabolize plasma intermediate density lipoproteins (IDL) and LDL inefficiently, and the lipoproteins accumulate to high levels in plasma, which produces fulminant atherosclerosis. The consequences of the receptor defect in these homozygous animals are quite similar to the consequences in children with homozygous familial hypercholesterolemia (1).

The mutation in WHHL rabbits has recently been characterized at the protein level in cultured rabbit fibroblasts (5). The LDL receptor of normal rabbits (5), like that of humans (6), is initially synthesized as a precursor with an apparent molecular weight of 120,000 , as determined by sodium dodecyl sulfate (SDS)-polyacrylamide gel electrophoresis under sulfhydryl reducing conditions. Within 15-30 min, the apparent molecular weight of the receptor shifts to 160,000 on SDS gels, apparently owing to the elongation of $O$-linked oligosaccharide chains in a series of reactions that are believed to occur in the Golgi complex (7). Soon thereafter, the receptor appears on the cell surface as a 160,000-D glycoprotein. In WHHL rabbits, as in certain patients with familial hypercholesterolemia (the $O$. family), the LDL receptor precursor is synthesized as a normally appearing 120,000-D protein (5). However, in contrast to the normal precursor, the precursor

1. Abbreviations used in this paper: CHAPS, 3-([cholamidopropyl]dimethylammonio)-1-propane sulfonate; WHHL rabbit, Watanabe Heritable Hyperlipidemic rabbit. 
in the WHHL rabbits and in the 0 . family is transported to the surface slowly and the oligosaccharide chains are modified at $<10 \%$ of the normal rate (5). As a result, most of the receptors remain inside the cell where they are unable to perform their normal functions.

The advantage of the WHHL rabbit lies in the use of these animals for whole-body experiments that are not possible in humans with familial hypercholesterolemia. Indeed, previous studies in these animals have shown that the slow fractional rate of catabolism of plasma $\operatorname{LDL}(1,2,8,9)$ is due primarily to inefficient uptake of LDL in the liver and adrenal gland, the two organs that rely most heavily on LDL receptors for rapid LDL uptake (9).

In the current studies we have prepared a mouse monoclonal antibody that reacts with the rabbit LDL receptor and have used this antibody to probe the expression of LDL receptors in intact rabbits. In particular, we show that the adrenal glands of WHHL rabbits, like WHHL fibroblasts in tissue culture, accumulate the low molecular weight precursor form of the receptor. We also show that the mutant LDL receptor is not detectable structurally in the liver of WHHL rabbits. Finally, we show that WHHL rabbits remove ${ }^{125} \mathrm{I}$-labeled anti-receptor monoclonal antibody from the circulation much more slowly than normal rabbits. This latter result raises the general possibility that the rate of catabolism of an ${ }^{125} \mathrm{I}$-labeled monoclonal antibody directed against a cell surface receptor can be used as an index of the number of those receptors in animals and humans.

\section{Methods}

Materials. We obtained 3-[(cholamidopropyl]dimethylammonio]-1propane sulfonate (CHAPS) from Sigma Chemical Co., St. Louis, MO; nitrocellulose from Schleicher and Schuell, Inc., Keene, NH; rabbit anti-mouse IgG (IgG fraction, No. 0211-0082) from Cappel Laboratories, Inc., Cochranville, PA; and Iodogen (1,3,4,6-tetrachloro-3 $\alpha, 6 \alpha$-diphenylglycoluril) from Pierce Chemical Co., Rockford, IL. All other materials were obtained from previously reported sources $(5,6$, $10,11)$.

Rabbits. New Zealand white rabbits ("normal rabbits") were purchased from Hickory Hill Rabbitry (Flint, TX). Homozygous WHHL rabbits were raised in Dallas as described $(3,12)$. Animals were fed Purina rabbit chow and were 3-5 mo old (2-3.5 kg of body weight) at the time of study.

Lipoproteins. Rabbit LDL ( $d=1.019-1.050 \mathrm{~g} / \mathrm{ml})$ from normal animals and rabbit $\beta$-migrating very low density lipoproteins ( $\beta$-VLDL) from cholesterol-fed animals were isolated as described previously (3, 13). Human LDL $(d=1.019-1.063 \mathrm{~g} / \mathrm{ml})$ was prepared from plasma of individual healthy subjects (14). Plasma cholesterol levels were measured by the cholesterol oxidase method (13).

Cultured cells. Cultured fibroblasts from normal and WHHL rabbits were derived from explants of skin and grown in monolayer culture as previously described (5).

Monoclonal antibodies. Monoclonal antibodies were produced by modification (15) of the hybridoma technique of Köhler and Milstein (16). Purified bovine LDL receptors (10) were digested proteolytically by incubation for $16 \mathrm{~h}$ at $37^{\circ} \mathrm{C}$ with $2.5 \mu \mathrm{g}$ of trypsin (type XIII, No.
T-8642, Sigma Chemical Co.). The digested receptor (50 $\mu \mathrm{g}$ for each injection) was injected intraperitoneally into mice on days 0,14 , and 91 after emulsification with an equal volume of either complete (day 0 ) or incomplete (days 14 and 91) Freund's adjuvant. The fusion of splenocytes with P3-X63-Ag8.653 mouse myeloma cells (17) was carried out on day 95 . Of the 1,632 wells that received aliquots of the fusion mixture, 98 produced visible clusters of hybridomas. Of these 98 wells, eight produced antibodies that bound to the purified bovine LDL receptor as measured by a solid-phase indirect binding assay (15). After cloning and subcloning, the media from these eight hybridomas were tested for recognition of the purified LDL receptor from rabbit adrenal glands (5) by a solid-phase indirect binding assay (15) and by immunoblotting after SDS-polyacrylamide gel electrophoresis as described below. One of the eight clones produced an antibody, designated IgG-9D9, that cross-reacted with the rabbit LDL receptor. The control monoclonal antibody IgG-A9, directed against hamster 3-hydroxy-3methylglutaryl CoA reductase, was produced in mouse hybridomas as previously described (18). IgG-9D9 and IgG-A9 were isolated from ascites fluid by chromatography on columns of protein A-Sepharose CL-4B (15) or on columns of goat anti-mouse IgG coupled to Sepharose CL-4B. Both antibodies contained heavy chains of the IgG-1 subclass.

Radioiodination procedures. Lipoproteins were labeled with ${ }^{125} \mathrm{I}$ with the iodine monochloride method (14) to specific activities of 1-5 $\times 10^{5} \mathrm{cpm} / \mu \mathrm{g}$ protein. For ${ }^{125}$ I-labeled human $\mathrm{LDL}$ and rabbit LDL, $\sim 3 \%$ of the radioactivity was in lipid, as determined by chloroform/ methanol extraction (14). The monoclonal antibodies, IgG-9D9 and IgG-A9, were radiolabeled with the Iodogen method (15) with ${ }^{125}$ I or ${ }^{131}$ I as indicated to specific activities of $\sim 1 \times 10^{6} \mathrm{cpm} / \mu \mathrm{g}$. Rabbit antimouse $\mathrm{IgG}_{\mathrm{g}}$ antibody (IgG fraction) was radiolabeled with the chloramine $T$ method (19) to specific activities of $\sim 1 \times 10^{7} \mathrm{cpm} / \mu \mathrm{g}$ protein.

SDS-gel electrophoresis. One-dimensional electrophoresis of $7 \%$ SDS-polyacrylamide slab gels was carried out in the absence of reducing agents as previously described (11). Gels were calibrated with the following molecular weight standards: myosin, 200,000; phosphorylase $b, 97,000$; bovine serum albumin, 68,000; and ovalbumin, 43,000 .

Immunoblotting. Electrophoretic transfer of proteins from SDS slab gels to nitrocellulose paper, incubation of the nitrocellulose with antibodies, and autoradiography were carried out as described $(20,21)$. The monoclonal antibodies, IgG-9D9 and IgG-A9, were used at a concentration of $10 \mu \mathrm{g} / \mathrm{ml}$, and ${ }^{125} \mathrm{I}$-labeled rabbit anti-mouse IgG antibody (IgG fraction) was used at a concentration of $0.5 \mu \mathrm{g} / \mathrm{ml}$ and a specific radioactivity of $\sim 1 \times 10^{7} \mathrm{cpm} / \mu \mathrm{g}$.

Ligand blotting. Proteins from SDS slab gels were transferred electrophoretically to nitrocellulose paper $(11,20)$. The paper was then incubated for $1 \mathrm{~h}$ at $37^{\circ} \mathrm{C}$ in buffer $\mathrm{A}$ (11) with ${ }^{125}$ I-labeled human LDL (4 $\mu$ g protein $/ \mathrm{ml} ; \sim 4 \times 10^{5} \mathrm{cpm} / \mu \mathrm{g}$ protein), washed with buffer B (11), rinsed with buffer containing $50 \mathrm{mM}$ Tris-chloride and $2 \mathrm{mM}$ $\mathrm{CaCl}_{2}$ at $\mathrm{pH} \mathrm{8}$, dried, and subjected to autoradiography as described by Daniel et al. (11). Molecular weight calibration was carried out as described (20).

Intravenous injection of ${ }^{125}{ }^{1-}$ or ${ }^{131}$ I-labeled monoclonal antibodies and measurement of tissue content of ${ }^{125}{ }^{2}$ - and ${ }^{131} I$-radioactivity. Normal and WHHL rabbits, matched for sex and body weight, were studied in the fed state. All animals were unanesthetized and were kept in restraining cages. The ${ }^{125} \mathrm{I}-$ or ${ }^{131} \mathrm{I}$-labeled monoclonal antibody was mixed with $1 \mathrm{ml}$ of autologous rabbit plasma and injected into the marginal ear vein. Serial 1-2-ml blood samples were collected over $6 \mathrm{~h}$ from the ear artery in tubes that contained EDTA. The plasma was subjected to scintillation counting. The $100 \%$ value for plasma 
radioactivity was determined by measurement of the radioactivity in a plasma sample obtained 5 min after injection. In pilot experiments we found that $>97 \%$ of the radioactivity in plasma at all time points was precipitable with trichloroacetic acid, which implies that it represents undegraded antibody. In experiments in which tissues were obtained, immediately before termination of the experiment the animals were anesthetized and perfused through the portal vein in situ with a solution that contained $150 \mathrm{mM} \mathrm{NaCl}$ and $1 \mathrm{mM} \mathrm{CaCl}_{2}(22)$. Various organs were then removed, weighed, and cut either into $\sim 1-\mathrm{g}$ pieces for assay of ${ }^{125} \mathrm{I}$ - or ${ }^{131} \mathrm{I}$-radioactivity (liver, kidneys, and lungs) or counted directly as whole organs (adrenals and spleen) (13).

Whole blood exchange. Male WHHL rabbits were anesthetized with xylazine and ketamine, and a polyethylene catheter was inserted in the internal jugular vein as described (8). The animals were allowed to recover from surgery 24-48 $\mathrm{h}$ before they were studied. For each exchange, $35 \mathrm{ml}$ of blood was removed from a nonfasted WHHL rabbit, and this was replaced with an equal volume of blood from a normal rabbit that had been fasted for $24 \mathrm{~h}$. The donor blood was collected by heart puncture in a citrate/phosphate/dextrose anticoagulant solution. The exchange was repeated five times with an equilibration time of $3 \mathrm{~min}$ between exchanges. $2 \mathrm{~h}$ after the last exchange, the WHHL rabbits were injected with ${ }^{125}$ I-IgG-9D9 and its catabolism was measured. After $10 \mathrm{~d}$, at a time when the plasma cholesterol levels had risen to their pretransfusion values, the same WHHL rabbits were reinjected with ${ }^{125}$ I-IgG-9D9 and its catabolism was again measured.

\section{Results}

Preparation of a monoclonal antibody that reacts with the rabbit LDL receptor. Our previous anti-LDL receptor monoclonal antibodies were directed against bovine and human LDL receptors (reference 15 and unpublished data). None of these antibodies cross-reacted with the rabbit LDL receptor. Immunization of mice with partially purified LDL receptors from the rabbit adrenal gland failed to produce a high affinity monoclonal antibody. Therefore, we used an alternate approach. The purified bovine adrenal LDL receptor was treated with trypsin, and the tryptic fragments were used to immunize mice. Hybridomas were prepared from the mouse spleens, and the clones were assayed for secretion of an antibody that would react with purified LDL receptors from rabbit adrenal gland. One clone, designated 9D9, produced an antibody with heavy chains of the IgG-1 subclass that reacted with the rabbit adrenal LDL receptor. This antibody was designated IgG-9D9.

Fig. 1 compares the binding of ${ }^{125}$ I-labeled-IgG-9D9 to the surface of fibroblasts cultured from normal and WHHL fibroblasts. Normal rabbit fibroblasts, grown in the absence of LDL, bound ${ }^{125} \mathrm{I}-\mathrm{IgG}-9 \mathrm{D} 9$ with high affinity (Fig. $1 \mathrm{~A}$ ). When the cells were incubated with 25-hydroxycholesterol plus cholesterol so as to suppress the synthesis of LDL receptors (23), the high affinity binding of ${ }^{125} \mathrm{I}-\mathrm{IgG}-9 \mathrm{D} 9$ was reduced. Fibroblasts from WHHL rabbits bound very little ${ }^{125} \mathrm{I}-\mathrm{IgG}-9 \mathrm{D} 9$, with no detectable high affinity component (Fig. $1 B$ ). There was no reduction in this binding when sterols were present, which confirmed that the small amounts of observed binding in WHHL rabbit fibroblasts did not represent binding to LDL receptors.

In addition to binding ${ }^{125} \mathrm{I}-\mathrm{IgG}-9 \mathrm{D} 9$ at the cell surface,

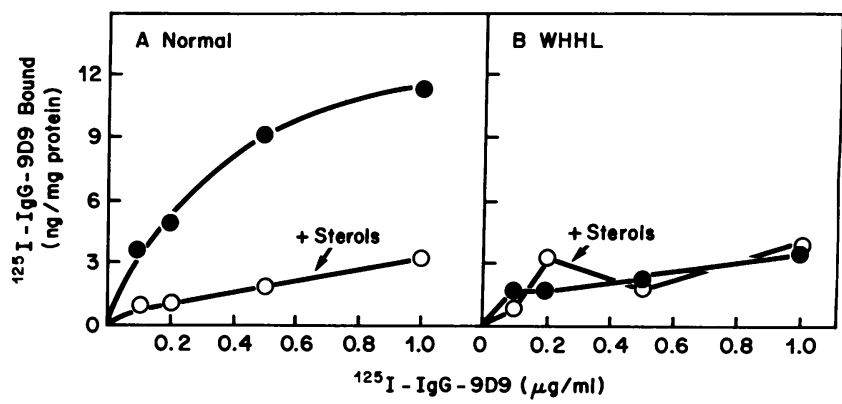

Figure 1. Cell surface binding at $4^{\circ} \mathrm{C}$ of ${ }^{125}$ I-labeled anti-LDL receptor monoclonal antibody IgG-9D9 to fibroblasts from normal $(A)$ and WHHL $(B)$ rabbits cultured in the absence $(\bullet)$ or presence $(0)$ of sterols. On day 0 of growth, $5 \times 10^{4}$ cells were seeded into each Petri dish $(60 \times 15-\mathrm{mm})$, which contained $3 \mathrm{ml}$ of medium A (Dulbecco's modified Eagle's medium containing $100 \mathrm{U} / \mathrm{ml}$ penicillin and 100 $\mu \mathrm{g} / \mathrm{ml}$ streptomycin) that was supplemented with $10 \%$ (vol/vol) NuSerum (5). On day 2, the medium was replaced with $3 \mathrm{ml}$ of fresh medium A with $10 \% \mathrm{Nu}$-Serum. On day 3, each monolayer was washed with $2 \mathrm{ml}$ of Dulbecco's phosphate-buffered saline and then switched to medium $A$ that was supplemented with $5 \mu \mathrm{g} / \mathrm{ml}$ insulin, $5 \mu \mathrm{g} / \mathrm{ml}$ transferrin, and $5 \mathrm{ng} / \mathrm{ml}$ selenium (ITS Premix) (5) and $10 \%$ (vol/vol) newborn calf lipoprotein-deficient serum in the absence or presence of $1 \mu \mathrm{g} / \mathrm{ml}$ of 25-hydroxycholesterol plus $15 \mu \mathrm{g} / \mathrm{ml}$ cholesterol. Fresh medium of the same composition was added on day 4. On day 5 , each monolayer received ice-cold medium that contained 5\% lipoprotein-deficient serum plus the indicated concentration of monoclonal ${ }^{125} \mathrm{I}-\mathrm{IgG}-9 \mathrm{D} 9$ ( $\left.739 \mathrm{cpm} / \mathrm{ng}\right)$. After incubation for $2 \mathrm{~h}$ at $4^{\circ} \mathrm{C}$, the total radioactivity bound to the cells was determined (15). Each value represents the average of duplicate incubations.

normal rabbit fibroblasts internalized and degraded the antibody to trichloroacetic acid-soluble material in a receptor-dependent fashion (Table I). After incubation with ${ }^{125} \mathrm{I}-\mathrm{IgG}-9 \mathrm{D} 9$ for $5 \mathrm{~h}$, normal rabbit fibroblasts contained $607 \mathrm{ng}$ of the antibody per milligram of cell protein and had degraded $398 \mathrm{ng} / \mathrm{mg}$ protein. The WHHL fibroblasts took up and degraded $<7 \%$ of the normal amount of the monoclonal antibody.

Detection of the $L D L$ receptor after electrophoresis of adrenal and liver membrane proteins. Adrenal glands of normal and WHHL rabbits were homogenized, and a crude 100,000 $g$ pellet of membranes was solubilized and subjected to electrophoresis in SDS-polyacrylamide gels in the absence of a sulfhydryl reducing agent. The proteins were transferred to nitrocellulose paper, which was incubated with monoclonal IgG-9D9 followed by an ${ }^{125}$ I-labeled rabbit anti-mouse IgG. Adrenal membranes from normal rabbits showed a major immunoreactive band at $\sim 130,000 \mathrm{D}$ (Fig. 2), which corresponds to the known migration of the mature LDL receptor in the absence of reducing agents (reference 11 and see Discussion). There was also a minor band at $\sim 90,000 \mathrm{D}$, which corresponds to the migration of the unprocessed receptor precursor under the same nonreducing conditions (reference 11 and see Discussion). The adrenal membranes from WHHL rabbits had no detectable 130,000-D mature receptor. However, 
Table 1. Receptor-mediated Endocytosis of Monoclonal ${ }^{125}$ IIgG-9D9 by Fibroblasts from Normal and WHHL Rabbits

\begin{tabular}{lll}
\hline & & \\
\cline { 2 - 3 } Source of fibroblasts & Cellular content & Degradation \\
\hline & $n g / m g$ protein & $n g / m g$ protein \\
Normal & 607 & 398 \\
WHHL & 42 & 22 \\
\hline
\end{tabular}

Monolayers of fibroblasts were set up for experiments as described in the legend to Fig. 1. On day 5 after incubation for $48 \mathrm{~h}$ in lipoprotein-deficient serum, each monolayer received $2 \mathrm{ml}$ of medium that contained 5\% lipoprotein-deficient serum and $10 \mu \mathrm{g} / \mathrm{ml}$ of ${ }^{125} \mathrm{I}-\mathrm{IgG}$ $9 D 9(130 \mathrm{cpm} / \mathrm{ng})$ in the absence or presence of $350 \mu \mathrm{g} / \mathrm{ml}$ of unlabeled IgG-9D9. After incubation for $5 \mathrm{~h}$ at $37^{\circ} \mathrm{C}$, the total cellular content (surface-bound + intracellular) and degradation of ${ }^{125} \mathrm{I}$-IgG9D9 were determined (15). The data shown represent high affinity values, which were calculated by subtracting the values obtained in the presence of excess unlabeled IgG-9D9 (nonspecific values) from those obtained in the absence of unlabeled IgG-9D9 (total values). The nonspecific values for cellular content in the normal and WHHL cells were 87 and $41 \mathrm{ng} / \mathrm{mg}$, respectively; the nonspecific values for degradation in the two cell strains were 254 and $173 \mathrm{ng} / \mathrm{mg}$, respectively. Each value represents the average of duplicate incubations.

these glands contained relatively large amounts of the 90,000 D material, which corresponds to the unprocessed precursor. These findings in adrenal homogenates were consistent with previous studies in cultured WHHL fibroblasts, which indicated that the mutant receptor produced by the WHHL rabbits is not processed to the mature form at a normal rate and therefore it remains predominantly in the precursor form (5).

IgG-9D9 also bound to the LDL receptor of normal rabbit liver (Fig. 3). Because of the lower concentration of receptor in liver as compared with the adrenals, it was first necessary to partially purify the receptor by elution from a DEAEcellulose column. Fig. $3 \mathrm{~A}$ shows an immunoblot of an SDSpolyacrylamide gel of fractions eluted from such a column. Immunoreactive receptor emerged from the column in fractions 16 through 22, with a peak at fraction 18. When the same experiment was performed on extracts of WHHL liver membranes, no immunoreactive LDL receptor was seen (Fig. 3 B).

The mature LDL receptor protein of normal rabbit liver that bound IgG-9D9 also bound human LDL. Fig. $4 A$ shows a ligand blot performed on fractions that were obtained from a DEAE-cellulose column of normal rabbit liver extracts, which were subjected to SDS-gel electrophoresis, transferred to nitrocellulose, and incubated with ${ }^{125} \mathrm{I}-\mathrm{LDL}$. The ${ }^{125} \mathrm{I}-\mathrm{LDL}$ bound to the mature receptor in fractions 15 through 24 . No ${ }^{125} \mathrm{I}-\mathrm{LDL}$ bound to the corresponding fractions from membranes of a WHHL rabbit liver (Fig. $4 \mathrm{~B}$ ).

Use of monoclonal ${ }^{125} I-I g G-9 D 9$ turnover measurements to estimate the number of $L D L$ receptors in vivo. When ${ }^{125} \mathrm{I}$ -

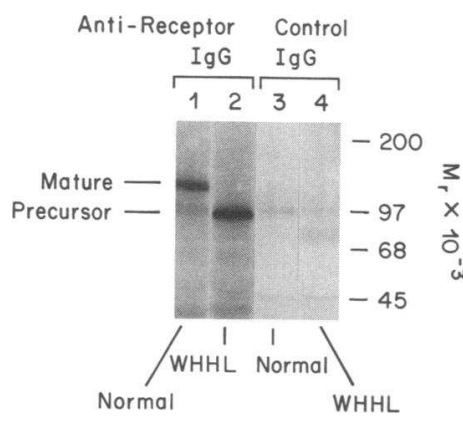

Figure 2. Immunoblotting of $L D L$ receptors from the adrenal glands of normal (lanes 1 and 3 ) and WHHL (lanes 2 and 4) rabbits. Adrenal glands from two rabbits were dissected free of fat, diced, and homogenized in buffer that contained $20 \mathrm{mM}$ Tris-chloride (pH 8), $1 \mathrm{mM} \mathrm{CaCl} 2,150$ $\mathrm{mM} \mathrm{NaCl}$, and $1 \mathrm{mM}$ phenylmethylsulfonyl-

fluoride with 20 strokes of a loose-fitting pestle in a Dounce homogenizer. All operations were carried out at $0-4^{\circ} \mathrm{C}$. The homogenates were spun at $100,000 \mathrm{~g}$ for $1 \mathrm{~h}$, and the pellets were resuspended in buffer that contained $20 \mathrm{mM}$ Tris-chloride (pH 8 ) and $1 \mathrm{mM}$ phenylmethylsulfonyl fluoride by aspiration through a 22-gauge needle to a final protein concentration of $2 \mathrm{mg} / \mathrm{ml}$. Triton X-100 was added to a final concentration of $1 \%(\mathrm{vol} / \mathrm{vol})$. After incubation for $10 \mathrm{~min}$ at $4^{\circ} \mathrm{C}$, insoluble material was removed by centrifugation at $100,000 \mathrm{~g}$ for $1 \mathrm{~h}$. An equal volume of buffer that contained $20 \%$ (vol/vol) glycerol, $125 \mathrm{mM}$ Tris-chloride (pH 6.8), and 4.6\% (wt/vol) SDS was added to the supernatant, and the mixture was spun in a microfuge for $5 \mathrm{~min}$. Aliquots $(250 \mu \mathrm{l})$ of the resulting supernatant were subjected to 7\% SDS-gel electrophoresis with nonreducing conditions, electrophoretic transfer to nitrocellulose, and immunoblotting with IgG-9D9 (lanes 1 and 2) and IgG-A9 (lanes 3 and 4) as described in Methods. The nitrocellulose sheet was exposed to x-ray film for $24 \mathrm{~h} . M_{\mathrm{r}}$ standards are indicated.

labeled IgG-9D9 was administered intravenously to normal rabbits, the radioactivity was rapidly cleared from plasma, with $50 \%$ removed in 1-2 h (Fig. $5 \mathrm{~A}$ ). When the same radiolabeled antibody was administered to WHHL rabbits, the radioactivity was removed from the circulation much more slowly. By $6 \mathrm{~h}$, $<40 \%$ of the antibody had been removed from the circulation (Fig. $5 \mathrm{~A}$ ). IgG-A9, a control monoclonal IgG of the same subclass as IgG-9D9, was used to test the specificity of catabolism of ${ }^{125} \mathrm{I}$-IgG-9D9 in rabbits. IgG-A9 is directed against hamster 3-hydroxy-3-methylglutaryl CoA reductase, an intracellular enzyme that should not be accessible to the monoclonal immunoglobulin in the plasma. ${ }^{125} \mathrm{I}-\mathrm{IgG}-\mathrm{A} 9$ disappeared slowly from the plasma in both normal and WHHL rabbits (Fig. $5 B)$.

Table II shows the distribution of radioactivity in various tissues of normal and WHHL rabbits $1 \mathrm{~h}$ after injection of a mixture of anti-receptor ${ }^{125} \mathrm{I}-\mathrm{IgG}-9 \mathrm{D} 9$ and control ${ }^{131} \mathrm{I}-\mathrm{IgG}-\mathrm{A} 9$. In the normal animals two tissues, liver and adrenal, took up 4- and 24-fold more ${ }^{125} \mathrm{I}-\mathrm{IgG}$-9D9 than the control ${ }^{131} \mathrm{I}-\mathrm{IgG}$ A9. In the WHHL rabbits there was no selective uptake of ${ }^{125} \mathrm{I}-\mathrm{IgG}-9 \mathrm{D} 9$ in these two tissues (the ratios of uptake of ${ }^{125} \mathrm{I}$ IgG-9D9 to ${ }^{131} \mathrm{I}-\mathrm{IgG}-\mathrm{A} 9$ in these tissues in WHHL rabbits were 0.5 and 1.0 , respectively). These findings suggest that the rapid uptake of the ${ }^{125} \mathrm{I}-\mathrm{IgG}-9 \mathrm{D} 9$ in normal liver and adrenal glands is mediated by the LDL receptor. The spleen, lungs, and 

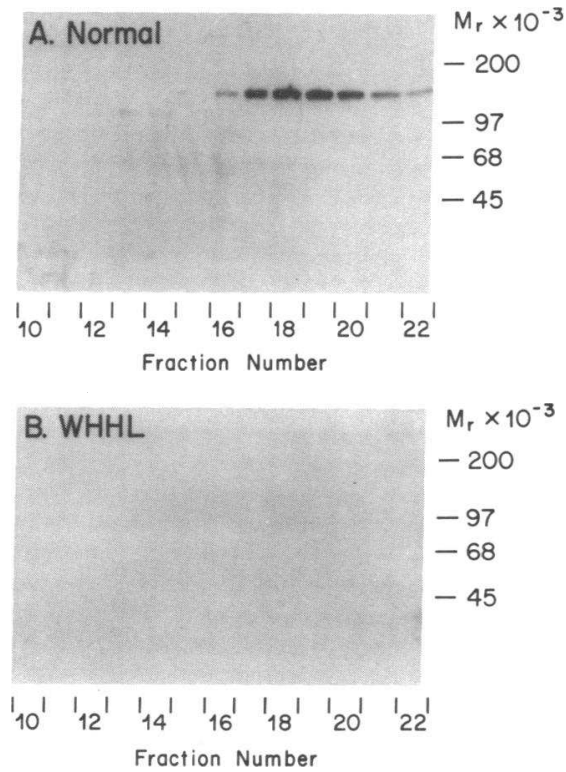

Figure 3. Immunoblotting of LDL receptors from the liver of normal $(A)$ and WHHL $(B)$ rabbits. Livers were perfused in situ with a solution that contained $150 \mathrm{mM} \mathrm{NaCl}$ and $1 \mathrm{mM} \mathrm{CaCl}_{2}$ via the portal vein for $3 \mathrm{~min}(12)$ and immediately placed in ice-cold buffer that contained $20 \mathrm{mM}$ Tris-chloride (pH 8), $1 \mathrm{mM} \mathrm{CaCl}, 150 \mathrm{mM}$ $\mathrm{NaCl}$, and $1 \mathrm{mM}$ phenylmethylsulfonylfluoride. Membrane pellets from $70 \mathrm{~g}$ (wet weight) of each liver were prepared (30), and solubilized with detergent as described (10), except that 20 mM CHAPS was used instead of $1 \%$ (vol/vol) Triton X-100. DEAE-cellulose chromatography of each of the two detergent extracts $(610 \mathrm{mg}$ protein in each extract) was carried out on identical columns as previously described (10) except that $20 \mathrm{mM}$ CHAPS was substituted for $1 \%$ Triton X-100. The columns were eluted with an $80-\mathrm{ml}$ linear gradient of $0-350 \mathrm{mM} \mathrm{NaCl}$ in buffer that contained $50 \mathrm{mM}$ Trismaleate (pH 6), $2 \mathrm{mM} \mathrm{CaCl}_{2}$, and $40 \mathrm{mM}$ octylglucoside. Fractions of $3.2 \mathrm{ml}$ were each collected, and $70 \mu \mathrm{l}$ of corresponding fractions from the normal rabbit $(A)$ and the WHHL rabbit $(B)$ were subjected to electrophoresis on 7\% SDS slab gels with nonreducing conditions, followed by transfer to nitrocellulose paper, and immunoblotting with IgG-9D9 and ${ }^{125}$ I-labeled rabbit anti-mouse IgG, as described in Methods. The nitrocellulose paper was exposed to x-ray film for 24 h. $M_{\mathrm{r}}$ standards are indicated.

kidneys showed no selective uptake of ${ }^{125} \mathrm{I}-\mathrm{IgG}-9 \mathrm{D} 9$ in either normal or WHHL animals.

The slow clearance from plasma and sluggish tissue uptake of ${ }^{125} \mathrm{I}$-IgG-9D9 in the WHHL rabbit can be attributed to a deficiency of LDL receptors in the liver and adrenal of these animals. However, it is also possible, theoretically at least, that LDL receptors might be expressed in WHHL rabbits, but that the high levels of circulating IDL and LDL might compete with ${ }^{125} \mathrm{I}-\mathrm{IgG}-9 \mathrm{D} 9$ for binding to the receptor. To examine whether such competition occurs, we determined whether rabbit LDL or $\beta$-VLDL (a high affinity ligand for the LDL receptor) $(3,24)$ would compete with ${ }^{125} \mathrm{I}$-IgG-9D9 for binding to the LDL receptor. For this purpose, we used partially
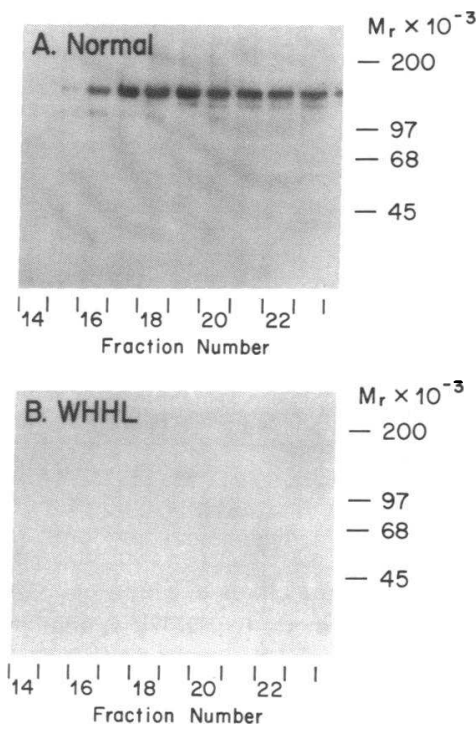

Figure 4. Ligand blotting of LDL receptors from the livers of normal $(A)$ and WHHL $(B)$ rabbits. DEAEcellulose column fractions were prepared from solubilized liver membranes, and aliquots $(70 \mu \mathrm{l})$ of each fraction were subjected to SDS-gel electrophoresis as described in the legend to Fig. 3. After electrophoretic transfer to nitrocellulose paper, ligand blotting with human ${ }^{125}$ I-LDL was carried out as described in Methods. The nitrocellulose paper was exposed to x-ray film for $30 \mathrm{~h}, M_{\mathrm{r}}$ standards are indicated. purified LDL receptors from bovine adrenal cortex. As expected, unlabeled rabbit $\beta$-VLDL and unlabeled rabbit LDL competed with ${ }^{125} \mathrm{I}$-rabbit LDL for binding to the LDL receptor in these preparations (Fig. $6 \mathrm{~A}$ ). Unlabeled IgG-9D9 showed a slight amount of competition, which reached a maximum of $\sim 30 \%$. The control IgG-A9 gave no competition. Fig. $6 B$ shows the converse experiment: Rabbit LDL did not compete with ${ }^{125} \mathrm{I}$ IgG-9D9 for LDL receptor binding. Rabbit $\beta$-VLDL showed a small amount of competition (maximum of $20 \%$ ). As expected, the control IgG-A9 did not compete with ${ }^{125} \mathrm{I}-\mathrm{IgG}$ 9D9, but unlabeled IgG-9D9 showed marked competition. These data also demonstrate that EDTA prevents the binding of ${ }^{125} \mathrm{I}$-IgG-9D9 to the LDL receptor (Fig. $6 \mathrm{~B}$ ). This inhibition by EDTA can be completely reversed by excess $\mathrm{Ca}^{++}$, which indicates that binding of ${ }^{125} \mathrm{I}-\mathrm{IgG}-9 \mathrm{D} 9$ to the $\mathrm{LDL}$ receptor has an absolute requirement for divalent cation (data not shown), just as has been observed with the ligands LDL and $\beta$-VLDL (Fig. $6 A$ and reference 3).

To further explore the possibility of lipoprotein competition for ${ }^{125} \mathrm{I}-\mathrm{IgG}-9 \mathrm{D} 9$ binding in vivo, we measured the disappearance of intravenously administered ${ }^{125} \mathrm{I}-\mathrm{IgG}-9 \mathrm{D} 9$ before and after the infusion of an extremely large dose of $\beta$-VLDL to normal rabbits. Fig. 7 shows that ${ }^{125} \mathrm{I}-\mathrm{IgG}-9 \mathrm{D} 9$ was removed rapidly from the blood of normal rabbits. When the rabbits were given sufficient $\beta$-VLDL to raise their total plasma cholesterol levels from 26 and $45 \mathrm{mg} / \mathrm{dl}$ to 759 and $869 \mathrm{mg} /$ dl, the removal of ${ }^{125} \mathrm{I}-\mathrm{IgG}-9 \mathrm{D} 9$ was slowed somewhat, but the removal rate was still much faster than that of the control monoclonal ${ }^{125} \mathrm{I}-\mathrm{IgG}$-A9 (Fig. 7 B). Prior injection of unlabeled $\beta$-VLDL had no effect on the removal of the control IgG (Fig. $7 \mathrm{~B}$ ). These data suggest that extremely high levels of a potential competing ligand are not able to abolish the receptormediated removal of ${ }^{125} \mathrm{I}-\mathrm{IgG}-9 \mathrm{D} 9$ from plasma of normal rabbits. 


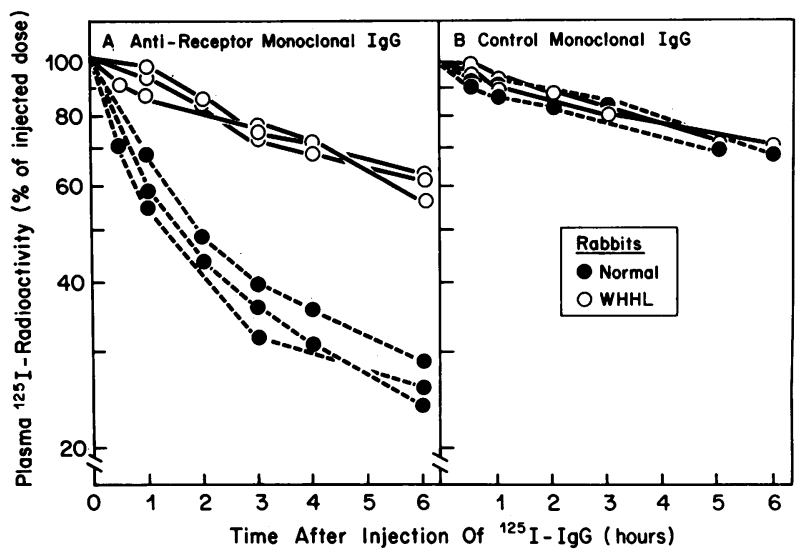

Figure 5. Plasma clearance curves after intravenous injection of ${ }^{125} \mathrm{I}$ labeled anti-LDL receptor monoclonal antibody $\operatorname{IgG-9D9}(A)$ and control monoclonal antibody IgG-A9 $(B)$ to normal $(\bullet)$ and WHHL (O) rabbits. 10 rabbits (females) were studied in pairs (one normal and one WHHL on each day). Each animal was injected with $\sim 2.6$ $\times 10^{7} \mathrm{cpm}$ of either ${ }^{125} \mathrm{I}-\mathrm{IgG}-9 \mathrm{D} 9(A)$ or ${ }^{125} \mathrm{I}-\mathrm{IgG}-\mathrm{A} 9(B)$. Blood samples were drawn at the indicated time and processed for scintillation counting as described in Methods.

To further test the possibility that the high levels of circulating endogenous lipoproteins were competing for removal of ${ }^{125} \mathrm{I}-\mathrm{IgG}-9 \mathrm{D} 9$ in WHHL rabbits, we removed aliquots of blood from the WHHL rabbits and replaced them with equal volumes of blood from normal rabbits, thereby lowering the cholesterol level in the WHHL rabbit. The clearance of intravenously administered ${ }^{125} \mathrm{I}$-IgG-9D9 was measured in each animal before and after such blood exchange (Fig. 8). The blood exchange reduced the plasma cholesterol level in two WHHL rabbits from 607 and $562 \mathrm{mg} / \mathrm{dl}$ to 182 and $175 \mathrm{mg} /$ dl, respectively. Despite this large reduction in the concentration of circulating lipoproteins, there was no increased rate of disappearance of ${ }^{125} \mathrm{I}-\mathrm{IgG}-9 \mathrm{D} 9$ in these animals.

\section{Discussion}

The current experiments extend our knowledge of the manifestations of the LDL receptor defect in intact animals. Through the use of a monoclonal antibody that reacts with the rabbit LDL receptor, we have made the following observations: (a) The adrenal gland of the WHHL rabbit accumulates an immunoreactive receptor with an apparent molecular weight that corresponds to that of the unprocessed precursor; $(b)$ in contrast to normal rabbit liver, the liver of the WHHL rabbit does not contain sufficient amounts of immunoreactive receptor to be visualized with current immunoblotting and ligand blotting techniques; and $(c)$ the rate of disappearance of intravenously administered anti-receptor monoclonal antibody is rapid in normal rabbits and markedly delayed in WHHL rabbits.

In previous studies of cultured fibroblasts, we found that the cells from WHHL rabbits synthesize a low molecular weight receptor precursor that resembles the precursor synthesized by normal rabbit fibroblasts (5). However, in WHHL rabbits the precursor is processed to the mature high molecular weight form at an abnormally slow rate (5). The low molecular weight precursor of the LDL receptor in human and rabbit cells migrates on SDS gels with a mobility corresponding to an apparent molecular weight of 120,000 when electrophoresis is performed in the presence of sulfhydryl reducing agents (57). Under these conditions, the apparent molecular weight of the processed mature receptor is $160,000(5-7)$. In the absence of reducing agents, the precursor of the human LDL receptor migrates with an apparent molecular weight of 90,000 and the mature form shows an apparent molecular weight of 130,000

Table II. Tissue Distribution of Radioactivity after Simultaneous Intravenous Injection of ${ }^{125}$ I-labeled Anti-Receptor

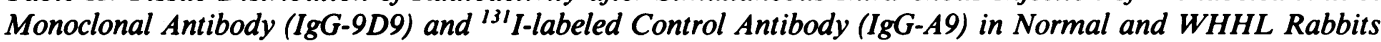

\begin{tabular}{|c|c|c|c|c|c|c|c|c|}
\hline \multirow[b]{2}{*}{ Organ } & \multicolumn{4}{|l|}{ Normal } & \multicolumn{4}{|l|}{ WHHL } \\
\hline & Weight of organ & ${ }^{125} \mathrm{I}-\mathrm{IgG}$-9D9 (a) & ${ }^{131} \operatorname{I}-\lg G-A 9(b)$ & Mean ratio: $(a) /(b)$ & Weight of organ & ${ }^{125} \mathrm{I}-\mathrm{IgG}-9 \mathrm{D} 9(a)$ & ${ }^{131} \mathrm{I}-\mathrm{IgG}-\mathrm{A} 9(b)$ & Mean ratio: $(a) /(b)$ \\
\hline & $g$ & \multicolumn{3}{|c|}{ \% of injected dose per $g$ tissue } & $g$ & \multicolumn{3}{|c|}{ \% of injected dose per g tissue } \\
\hline Liver & 78,70 & $0.39,0.36$ & $0.11,0.08$ & $4.0^{*}$ & 89,88 & $0.06,0.03$ & $0.09,0.09$ & $0.50^{*}$ \\
\hline Adrenal glands & $0.24,0.16$ & $1.8,1.5$ & $0.08,0.06$ & 24 & $0.13,0.15$ & $0.08,0.07$ & $0.08,0.07$ & 1.0 \\
\hline Spleen & $1.0,1.2$ & $0.07,0.12$ & $0.08,0.11$ & 1.0 & $0.92,1.1$ & $0.07,0.07$ & $0.11,0.10$ & 0.67 \\
\hline Lungs & 10,11 & $0.06,0.06$ & $0.05,0.06$ & 1.1 & 13,11 & $0.23,0.10$ & $0.13,0.07$ & 1.6 \\
\hline Kidneys & 14,13 & $0.13,0.09$ & $0.19,0.15$ & 0.64 & 15,19 & $0.11,0.07$ & $0.15,0.11$ & 0.68 \\
\hline
\end{tabular}

Two normal and two WHHL females were each injected with a mixture of ${ }^{125}$ I-IgG-9D9 $\left(4.7 \times 10^{7} \mathrm{cpm}\right)$ and ${ }^{131}$ I-IgG-A9 $\left(1.3 \times 10^{7} \mathrm{cpm}\right)$. After $1 \mathrm{~h}$, animals were killed and the ${ }^{125} \mathrm{I}$ - and ${ }^{131} \mathrm{I}$-radioactivity in the indicated tissues were measured by double-label scintillation counting. The results are expressed as percent of injected dose per gram of tissue, which is equal to (counts per minute per gram tissue divided by the counts per minute injected) $\times 10^{2}$. Each value represents the data from one animal. * The $(a) /(b)$ ratio represents the mean ratio of IgG-9D9 uptake to IgG-A9 uptake in the organs of the two animals. 


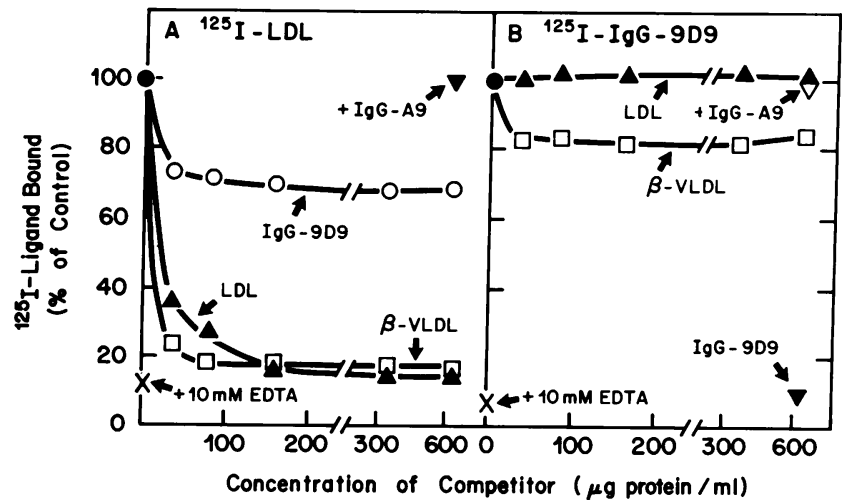

Figure 6. Competition by unlabeled ligands for binding of rabbit ${ }^{125}$ ILDL $(A)$ and anti-receptor monoclonal antibody ${ }^{125} \mathrm{I}-\mathrm{IgG}-9 \mathrm{D} 9(B)$ to partially purified LDL receptors from bovine adrenal cortex. Partially purified LDL receptors were obtained by DEAE-cellulose chromatography of detergent extracts prepared from bovine adrenal cortex (10). Binding of ${ }^{125} \mathrm{I}$-labeled ligands to partially purified LDL receptors was measured by the standard filtration assay as previously described (27). Each assay tube (100 $\mu \mathrm{l})$ contained $35 \mu \mathrm{g}$ of phosphatidylcholine/acetone-precipitated receptor protein (27), and incubations were carried out for $60 \mathrm{~min}$ at $24^{\circ} \mathrm{C}$ with either rabbit ${ }^{123} \mathrm{I}-\mathrm{LDL}(30 \mu \mathrm{g}$ protein $/ \mathrm{ml}$, specific activity of $2.4 \times 10^{5} \mathrm{cpm} / \mu \mathrm{g}$ protein) $(A)$ or ${ }^{125} \mathrm{I}$ IgG-9D9 $\left(20 \mu \mathrm{g} / \mathrm{ml}\right.$, specific activity of $\left.3.7 \times 10^{5} \mathrm{cpm} / \mu \mathrm{g}\right)(B)$. Binding assays were carried out in the presence of either $10 \mathrm{mM}$ EDTA or the indicated concentration of one of the indicated unlabeled ligands. The " $100 \%$ of control" values $(\bullet)$ were $117 \mathrm{ng}$ of ${ }^{125} \mathrm{I}-\mathrm{LDL}$ bound per filter $(A)$ and $364 \mathrm{ng}$ of ${ }^{125} \mathrm{I}-\mathrm{IgG}-9 \mathrm{D} 9$ bound per filter $(B)$.

(11). Our current ligand blotting and immunoblotting techniques can be used only when SDS-gel electrophoresis is performed in the absence of reducing agents $(11,20)$. Under these conditions the rabbit adrenal LDL receptor precursor has an apparent molecular weight of 90,000 and the mature form corresponds to a molecular weight of 130,000 (Fig. 2) as in human cells (11).

The current studies show that the low molecular weight receptor precursor accumulates in the adrenal glands of intact WHHL rabbits. Such accumulation is presumably due to the large demand for cholesterol for steroid hormone synthesis in the adrenal, which leads to the synthesis of large numbers of LDL receptors. In normal liver, the amount of LDL receptor activity per gram of tissue is only about one-tenth the amount present per gram of adrenal tissue (25). For this reason, we were unable to obtain definitive immunoblots after electrophoresis of crude liver membranes. Therefore, we had to partially purify the receptor by DEAE-cellulose chromatography before immunoblotting. With this procedure it was possible to visualize the mature high molecular weight LDL receptor in extracts of normal liver. We were not able to visualize any immunoreactive receptor in the WHHL liver extracts that were prepared in an identical fashion. The failure to observe a receptor precursor

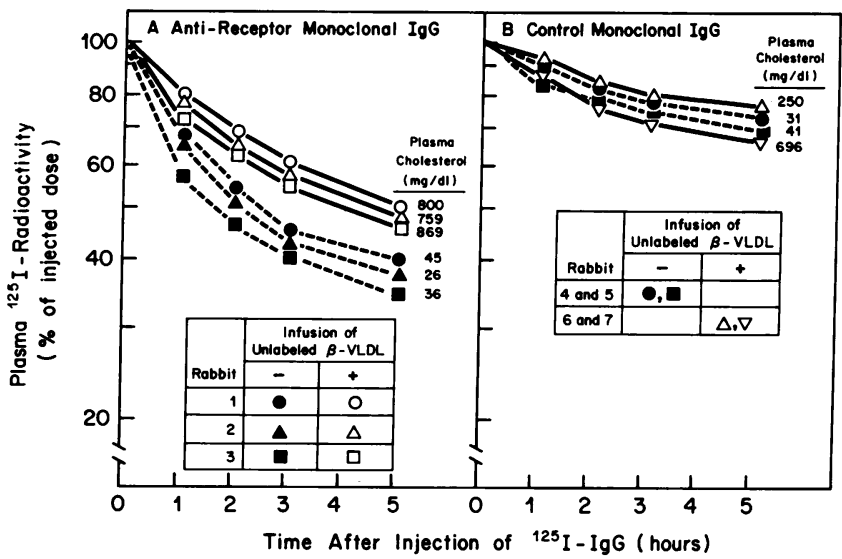

Figure 7. Effect of intravenously injected unlabeled $\beta$-VLDL on the removal of ${ }^{125}$ I-labeled anti-LDL receptor monoclonal antibody IgG9D9 $(A)$ and control monoclonal antibody IgG-A9 $(B)$ from the plasma of normal rabbits. $(A)$ Three normal male rabbits were each injected with $\sim 1.3 \times 10^{6} \mathrm{cpm}$ of ${ }^{125}$ I-IgG-9D9 $(\bullet, \Delta, \square)$ and blood samples were drawn at the indicated times. $6 \mathrm{~d}$ later, the same three animals were injected with unlabeled $\beta$-VLDL $(60 \mathrm{mg}$ protein given intravenously in $5 \mathrm{ml}$ of $0.15 \mathrm{M} \mathrm{NaCl}$ ) followed immediately by an injection of $\sim 2.6 \times 10^{7} \mathrm{cpm}$ of ${ }^{125}$ I-IgG-9D9 $(0, \Delta, \square)$. Blood samples were drawn at the indicated time and processed for scintillation counting as described in Methods. $(B)$ Four normal male rabbits were each injected with $\sim 2.6 \times 10^{7} \mathrm{cpm}$ of ${ }^{125} \mathrm{I}-\mathrm{IgG}-\mathrm{A} 9$ in the absence $(\bullet, \square)$ or presence $(\Delta, \nabla)$ of unlabeled $\beta$-VLDL as described in $A$. Rabbit $6(\Delta)$ and rabbit $7(\nabla)$ received 20 and $50 \mathrm{mg}$ protein of $\beta$-VLDL, respectively. Blood samples were drawn at the indicated time and processed for scintillation counting. The plasma cholesterol level of each animal $1 \mathrm{~h}$ after injection is shown.

in WHHL liver might be due to a failure of the precursor to be solubilized by the current procedure, or to a different behavior of the precursor during DEAE-cellulose chromatography. The precursor has a much lower negative charge than the mature receptor because of its lack of sialic acid (7). Therefore, it might be expected to behave differently upon solubilization and DEAE-cellulose chromatography. If a precursor does accumulate in the livers of WHHL rabbits, its demonstration will require further refinements of currently available analytical techniques.

The use of a radiolabeled monoclonal antibody plasma decay curve to estimate the number of receptors in vivo is of potential general importance. The usefulness of ${ }^{125} \mathrm{I}-\mathrm{IgG}-9 \mathrm{D} 9$ depends on a property of the LDL receptor known as receptor recycling. Previous studies in cultured fibroblasts have shown that the LDL receptor cycles in and out of cells about once every $10 \mathrm{~min}(26)$. If a monoclonal antibody is bound to the receptor, it moves into the cell with the receptor and is deposited in an endosome, which is the site at which the LDL dissociates from the receptor. The receptor then returns to the surface to bind a new molecule of LDL and antibody. The ${ }^{125} \mathrm{I}-\mathrm{IgG}-9 \mathrm{D} 9$ that is deposited in endosomes is eventually 


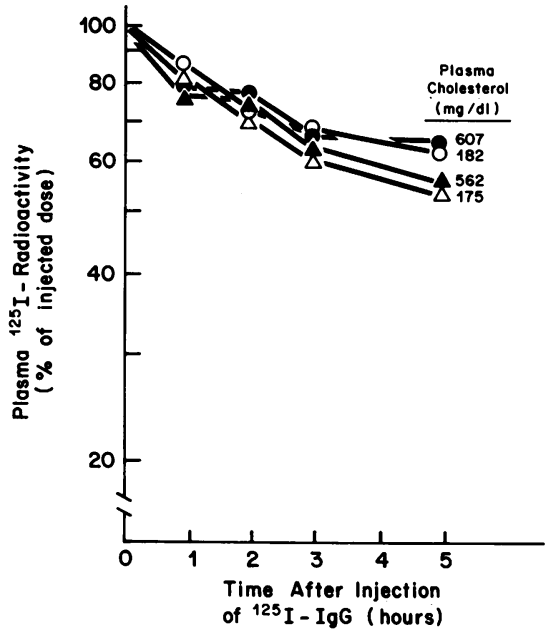

Figure 8. Removal of ${ }^{125}$ I-labeled anti-LDL receptor monoclonal antibody IgG-9D9 from the plasma of WHHL rabbits before and after reduction of plasma LDL levels by whole-blood exchange. Two male WHHL rabbits underwent exchange of whole blood with normal rabbits as described in Methods. After the plasma cholesterol level had been reduced to the value shown in the figure, each animal received an intravenous injection of $\sim 1.5 \times 10^{7} \mathrm{cpm}{ }^{125}$ I-IgG-9D9 $(0, \Delta)$, and blood samples were removed at the indicated intervals. Plasma cholesterol levels were measured on the 5-h sample. $10 \mathrm{~d}$ later, at a time when the plasma cholesterol levels had returned to the preexchange level as indicated in the figure, the same two animals were injected with $\sim 1.5 \times 10^{7} \mathrm{cpm}$ of ${ }^{125} \mathrm{I}-\mathrm{IgG}-9 \mathrm{D} 9(\bullet, \Delta)$. Blood samples were drawn at the indicated time and processed for scintillation counting.

transferred to lysosomes where it is degraded to amino acids, and the rate of this uptake and degradation is proportional to the number of recycling receptors. Whereas polyclonal antibodies fail to dissociate from the LDL receptor and thus trap the receptor inside the cell, monoclonal antibodies dissociate at acid $\mathrm{pH}$ and thus they do not deplete the cell surface of LDL receptors (27).

In normal rabbits, the anti-LDL receptor monoclonal antibody was removed from the plasma several times more rapidly (half-life, $\sim 1.5 \mathrm{~h}$ ) than a control IgG of the same subclass. The anti-receptor antibody also disappeared more rapidly than native LDL (half-life, $\sim 6 \mathrm{~h}$ ) (8) perhaps because the smaller size of the antibody allows more rapid penetration into interstitial spaces. This rapid clearance of monoclonal anti-receptor IgG-9D9 required the LDL receptor, since it did not take place in WHHL rabbits. In addition to the rapid clearance, which was restricted to normal rabbits, there was a slow clearance of ${ }^{125} \mathrm{I}$-IgG-9D9 that took place in both normal and WHHL rabbits and occurred equally with IgG-9D9 and the control IgG-A9. This slow clearance may represent slow removal of the antibodies from plasma by nonspecific mechanisms as well as distribution of the antibodies into slowly equilibrating tissue spaces.
The rapid disappearance of ${ }^{125} \mathrm{I}-\mathrm{IgG}-9 \mathrm{D} 9$ in normal rabbits was due primarily to rapid uptake into the liver. At $1 \mathrm{~h}$ the liver had taken up $\sim 30 \%$ of the total administered dose of ${ }^{125}$ I-IgG-9D9, which represented $80 \%$ of the total amount of IgG-9D9 that had disappeared from the plasma at this time point (Table II and Fig. 5). In contrast, at $1 \mathrm{~h}$ the liver contained only $7 \%$ of the total administered dose of the control antibody, ${ }^{131} \mathrm{I}$-IgG-A9. Although the adrenal glands showed the highest relative amount of receptor-mediated uptake of ${ }^{125} \mathrm{I}$-IgG-9D9 (24-fold greater uptake than that of control ${ }^{131} \mathrm{I}$ IgG-A9), the total contribution of the adrenals to overall ${ }^{125} \mathrm{I}$ IgG-9D9 clearance is small. The failure to find significant uptake of ${ }^{125} \mathrm{I}-\mathrm{IgG}-9 \mathrm{D} 9$ in the other tissues does not necessarily indicate an absence of functional LDL receptors in these tissues. The background in this type of assay is relatively high, i.e., relatively large amounts of the control ${ }^{131} \mathrm{I}-\mathrm{IgG}-\mathrm{A} 9$ accumulate in extracellular spaces. Therefore, it would be easy to miss a significant amount of specific receptor-mediated intracellular uptake of the ${ }^{125} \mathrm{I}$-IgG-9D9 on the basis of a 1 h-time point.

It should also be noted that the tissue content of ${ }^{125}$ Iradioactivity might represent a slight underestimate of LDL receptors since some of the ${ }^{125}$ I-radioactivity derived from degraded ${ }^{125} \mathrm{I}-\mathrm{IgG}-9 \mathrm{D} 9$ might have left the cell, even at the 1$\mathrm{h}$ time point. In this regard, it may be useful in future studies to label the monoclonal antibody with radioactive sucrose or tyramine cellobiose, which remain trapped in lysosomes after receptor-mediated endocytosis $(28,29)$.

In addition to its more rapid removal than LDL, the radioactive monoclonal anti-receptor antibody has another advantage over ${ }^{125} \mathrm{I}-\mathrm{LDL}$ for plasma turnover studies. This advantage stems from the observation that binding of ${ }^{125} \mathrm{I}$-IgG9D9 to the LDL receptor is inhibited only slightly by a marked excess of LDL or $\beta$-VLDL. One of the problems encountered in studying regulation of LDL receptors at the whole-animal level is in the area of competition between the administered tracer dose of radiolabeled lipoprotein and the endogenous unlabeled lipoproteins. For example, when rabbits were fed cholesterol, their ability to clear ${ }^{125} \mathrm{I}-\beta$-VLDL from the plasma diminished markedly (13). Part of this decrease was attributed to a suppression of hepatic LDL receptors, as determined by direct assays of ${ }^{125} \mathrm{I}-\beta$-VLDL binding to liver membranes. Part of the decrease in clearance was also due to excessive plasma levels of unlabeled $\beta$-VLDL, which competed with the ${ }^{125} \mathrm{I}-\beta$ VLDL for receptor occupancy (13). As a result, we were not able to conclude from the turnover studies alone that there was a suppression of LDL receptors after cholesterol feeding. The use of monoclonal ${ }^{125} \mathrm{I}-\mathrm{IgG}$-9D9 should circumvent the competition problem. Since marked elevations of circulating $\beta$-VLDL retard the clearance of ${ }^{125}$ I-IgG-9D9 only slightly in acute experiments, it should be possible to use the clearance of ${ }^{125}$ I-IgG-9D9 to follow the suppression of LDL receptors in cholesterol-fed animals without concern for the high circulating levels of $\beta$-VLDL. 
Many receptors, in addition to the LDL receptor, promote the uptake of their ligands through receptor-mediated endocytosis (26). Therefore, it should be possible to use plasma disappearance curves of monoclonal antibodies that are tagged with radioactivity or other markers to measure the relative number of these receptors at a whole-body level. If binding of the monoclonal antibodies is not competitively inhibited by the endogenous ligand and if these antibodies do not block receptor recycling, these antibodies can be used to assess the number of functioning receptors even when circulating ligand levels are high. If administration of tracer amounts of monoclonal antibodies to man is shown to be safe, one could use such monoclonal antibodies for diagnostic purposes in measuring either genetic or acquired regulatory defects in receptors, such as the reduction of insulin receptors in diabetes and the reduction of LDL receptors in humans with either genetic defects or on high cholesterol diets.

\section{Acknowledgments}

We are grateful to Martin Smith for help with the monoclonal antibodies and to Richard Gibson for help with the WHHL rabbits. Laurie Ledbetter, Sherri Gabbert, Claudia Stewart, and Wen-Ling Niu provided excellent technical assistance.

This work was supported by research grants from the National Institutes of Health (HL 20948 and HL 15949) and the Moss Heart Fund.

\section{References}

1. Goldstein, J. L., T. Kita, and M. S. Brown. 1983. Defective lipoprotein receptors and atherosclerosis. Lessons from an animal counterpart of familial hypercholesterolemia. N. Engl. J. Med. 309:288295.

2. Tanzawa, K., Y. Shimada, M. Kuroda, Y. Tsujita, M. Arai, and H. Watanabe. 1980. WHHL-rabbit. A low density lipoprotein receptordeficient animal model for familial hypercholesterolemia. FEBS (Fed. Eur. Biochem. Soc.) Lett. 118:81-84.

3. Kita, T., M. S. Brown, Y. Watanabe, and J. L. Goldstein. 1981. Deficiency of LDL receptors in liver and adrenal gland of the WHHL rabbit, an animal model of familial hypercholesterolemia. Proc. Natl. Acad. Sci. USA. 78:2268-2272.

4. Attie, A. D., R. C. Pittman, Y. Watanabe, and D. Steinberg. 1981. Low density lipoprotein receptor deficiency in cultured hepatocytes of the WHHL rabbit. Further evidence of two pathways for catabolism of exogenous proteins. J. Biol. Chem. 256:9789-9792.

5. Schneider, W. J., M. S. Brown, and J. L. Goldstein. 1983. Kinetic defects in the processing of the LDL receptor in fibroblasts from WHHL rabbits and a family with familial hypercholesterolemia. Mol. Biol. Med. 1:355-367.

6. Tolleshaug, H., J. L. Goldstein, W. J. Schneider, and M. S. Brown. 1982. Posttranslational processing of the LDL receptor and its genetic disruption in familial hypercholesterolemia. Cell. 30:715-724.

7. Cummings, R. D., S. Kornfeld, W. J. Schneider, K. K. Hobgood, H. Tolleshaug, M. S. Brown, and J. L. Goldstein. 1983. Biosynthesis of the $N$ - and $O$-linked oligosaccharides of the low density lipoprotein receptor. J. Biol. Chem. 258:15261-15273.
8. Bilheimer, D. W., Y. Watanabe, and T. Kita. 1982. Impaired receptor-mediated catabolism of low density lipoprotein in the WHHL rabbit, an animal model of familial hypercholesterolemia. Proc. Natl. Acad. Sci. USA. 79:3305-3309.

9. Pittman, R. C., T. E. Carew, A. D. Attie, J. L. Witztum, Y. Watanabe, and D. Steinberg. 1982. Receptor-dependent and receptorindependent degradation of low density lipoprotein in normal rabbits and in receptor-deficient mutant rabbits. J. Biol. Chem. 257:79948000.

10. Schneider, W. J., U. Beisiegel, J. L. Goldstein, and M. S. Brown. 1982. Purification of the low density lipoprotein receptor, an acidic glycoprotein of 164,000 molecular weight. J. Biol. Chem. 257:2664-2673.

11. Daniel, T. O., W. J. Schneider, J. L. Goldstein, and M. S. Brown. 1983. Visualization of lipoprotein receptors by ligand blotting. J. Biol. Chem. 258:4606-4611.

12. Kita, T., M. S. Brown, D. W. Bilheimer, and J. L. Goldstein. 1982. Delayed clearance of very low density and intermediate density lipoproteins with enhanced conversion to low density lipoprotein in WHHL rabbits. Proc. Natl. Acad. Sci. USA. 79:5693-5697.

13. Kovanen, P. T., M. S. Brown, S. K. Basu, D. W. Bilheimer, and J. L. Goldstein. 1981. Saturation and suppression of hepatic lipoprotein receptors. A mechanism for the hypercholesterolemia of cholesterol-fed rabbits. Proc. Natl. Acad. Sci. USA. 78:1396-1400.

14. Goldstein, J. L., S. K. Basu, and M. S. Brown. 1983. Receptormediated endocytosis of LDL in cultured cells. Methods Enzymol. 98:241-260.

15. Beisiegel, U., W. J. Schneider, J. L. Goldstein, R. G. W. Anderson, and M. S. Brown. 1981. Monoclonal antibodies to the low density lipoprotein receptor as probes for study of receptor-mediated endocytosis and the genetics of familial hypercholesterolemia. J. Biol. Chem. 256:11923-11931.

16. Köhler, G., and C. Milstein. 1975. Continuous cultures of fused cells secreting antibody of predefined specificity. Nature (Lond.). 256:495-497.

17. Kearney, J. F., A. Radbruch, B. Liesegang, and K. Rajewsky. 1979. A new mouse myeloma cell line that has lost immunoglobulin expression but permits the construction of antibody-secreting hybrid cell lines. J. Immunol. 123:1548-1550.

18. Liscum, L., K. L. Luskey, D. J. Chin, Y. K. Ho, J. L. Goldstein, and M. S. Brown. 1983. Regulation of 3-hydroxy-3-methylglutaryl coenzyme $A$ reductase and its $m R N A$ in rat liver as studied with a monoclonal antibody and a cDNA probe. J. Biol. Chem. 258:84508455.

19. McConahey, P. J., and F. J. Dixon. 1966. A method of trace iodination of proteins for immunologic studies. Int. Arch. Allergy 29:185-189.

20. Beisiegel, U., W. J. Schneider, M. S. Brown, and J. L. Goldstein. 1982. Immunoblot analysis of low density lipoprotein receptors in fibroblasts from subjects with familial hypercholesterolemia. J. Biol. Chem. 257:13150-13156.

21. Schneider, W. J., C. J. Slaughter, J. L. Goldstein, R. G. W. Anderson, D. J. Capra, and M. S. Brown. 1983. Use of anti-peptide antibodies to demonstrate external orientation of $\mathrm{NH}_{2}$-terminus of the LDL receptor in the plasma membrane of fibroblasts. J. Cell Biol. 97:1635-1640.

22. Kovanen, P. T., M. S. Brown, and J. L. Goldstein. 1979. Increased binding of low density lipoprotein to liver membranes from 
rats treated with $17 \alpha$-ethinyl estradiol. J. Biol. Chem. 254:1136711373.

23. Goldstein, J. L., and M. S. Brown. 1977. The low-density lipoprotein pathway and its relation to atherosclerosis. Ann. Rev. Biochem. 46:897-930.

24. Mahley, R. W., and T. L. Innerarity. 1983. Lipoprotein receptors and cholesterol homeostasis. Biochim. Biophys. Acta. 737:197222.

25. Kovanen, P. T., S. K. Basu, J. L. Goldstein, and M. S. Brown. 1979. Low density lipoprotein receptors in bovine adrenal cortex. II. Low density lipoprotein binding to membranes prepared from fresh tissue. Endocrinology. 104:610-616.

26. Goldstein, J. L., R. G. W. Anderson, and M. S. Brown. 1979. Coated pits, coated vesicles, and receptor-mediated endocytosis. Nature (Lond.). 279:679-685.
27. Anderson, R. G. W., M. S. Brown, U. Beisiegel, and J. L. Goldstein. 1982. Surface distribution and recycling of the LDL receptor as visualized by anti-receptor antibodies. J. Cell Biol. 93:523-531.

28. Pittman, R. C., A. D. Attie, T. E. Carew, and D. Steinberg. 1979. Tissue sites of degradation of low density lipoprotein. Application of a method for determining the fate of plasma proteins. Proc. Natl. Acad. Sci. USA. 76:5345-5349.

29. Pittman, R. C., T. E. Carew, C. K. Glass, S. R. Green, C. A. Taylor, Jr., and A. D. Attie. 1983. A radioiodinated, intracellularly trapped ligand for determining the sites of plasma protein degradation in vivo. Biochem. J. 212:791-800.

30. Schneider, W. J., J. L. Goldstein, and M. S. Brown. 1980. Partial purification and characterization of the low density lipoprotein receptor from bovine adrenal cortex. J. Biol. Chem. 255:11442-11447. 